\title{
Analisis Pengungkapan Modal Intelektual
}

\author{
Marfungatun Rahma, Minadi Wijaya*, Tunggul Priyatama \\ Universitas Wijayakusuma Purwokerto \\ *Coresponding Author: minadiw@unwiku.ac.id
}

\begin{abstract}
Abstrak. Penelitian ini bertujuan untuk menganalisis pengaruh ukuran perusahaan, profitabilitas, dan leverage terhadap pengungkapan modal intelektual pada perusahaan properti dan real estate yang terdaftar di BEI periode 2017-2019. Populasi dalam penelitian ini adalah perusahaan property dan real estate yang terdaftar di Bursa Efek Indonesia tahun 2017 - 2019. Sampel yang digunakan adalah 37 perusahaan property dan real estate dengan pengamatan selama tiga tahun yang berjumlah 111 unit analisis. Metode analisis yang digunakan adalah metode regresi berganda. Hasil penelitian ini menunjukkan bahwa ukuran perusahaan berpengaruh positif signifikan terhadap pengungkapan modal intelektual, sedangkan profitabilitas dan leverage tidak berpengaruh signifikan terhadap pengungkapan modal intelektual.
\end{abstract}

Kata kunci: Intellectual Capital Disclosure; Profitabilitas; Ukuran Perusahaan; leverage

Abstract. This study aims to analyze the effect of firm size, profitability, and leverage on intellectual capital disclosure in property and real estate companies listed on the IDX for the 2017-2019 period. The population in this study are property and real estate companies listed on the Indonesia Stock Exchange in 2017 - 2019. The sample used is 37 property and real estate companies with observations for three years totaling 111 units of analysis. The analytical method used is the multiple regression method. The results of this study indicate that firm size has a significant positive effect on intellectual capital disclosure, while profitability and leverage have no significant effect on intellectual capital disclosure.

\section{Keyword: Intellectual Capital Disclosure; Profitbility; Firm Size; Leverage}

\section{PENDAHULUAN}

Menghadapi persaingan bisnis saat ini, para pelaku bisnis perlu mengubah strategi bisnisnya yang semula berbasis tenaga kerja, menuju bisnis berbasis pengetahuan (knowledge-based business) (Yenita dan Efrizal, 2018). Oleh karena itu, para pelaku bisnis semakin menekankan pentingnya modal intelektual sebagai aset tidak berwujud. Kemampuan modal intelektual harus dipahami dan disadari oleh pelaku bisnis bahwa dalam melakukan persaingan bisnis tidak hanya terletak pada kemampuan modal fisik dan modal finansial saja, tetapi juga pada modal intelektual. Pada saat ini perusahaan disarankan untuk melakukan pengungkapan informasi yang bersifat sukarela (voluntary disclosure), terbuka dan jujur kepada masyarakat, pemegang saham, dan pihak yang berkepentingan lainnya. Terdapat beberapa alasan kenapa perusahaan harus mengungkapkan modal intelektual yaitu agar tidak ada kecurigaan pihak pemegang saham atas laporan keuangan, mengurangi penilaian buruk tentang perusahaan, dan untuk menunjukkan prospek kerja perusahaan yang semakin baik. Pemerintah telah mencanangkan rencana insentif pajak bagi industri atau investor yang terlibat dalam proses penelitian dan pengembangan, dengan tujuan untuk mendorong pencapaian tujuan investasi di Indonesia. Kegiatan penelitian dan pengembangan tersebut diharapkan dapat memicu perkembangan industri di sektor lain dan meningkatkan kesadaran serta perhatian perusahaan akan pentingnya modal intelektual disclosure dalam laporan tahunan (Suhardjanto dan Wardhani, 2010).

Hasil survei Price Waterhouse Coopers (Eccless, Herz, Keegan \& Philips, 2001) dan juga Taylor and Associates pada tahun 1998 (Williams, 2001) menunjukkan bahwa masalah yang terkait dengan modal intelektual disclosure adalah salah satu dari 10 informasi yang diminta oleh investor. Sepuluh tipe informasi yaitu ada tiga yang merupakan tipe informasi keuangan (cash flow, earnings, gross margin) dan sisanya yaitu tujuh yang terdiri dari data internal perusahaan (strategic direction dan competitive landscape) dan lima tipe lainnya yang dipertimbangkan adalah intangible (market growth, quality/experience of the management team, market size and market share, speed to market). Berdasarkan survey tersebut tipe informasi yang 4 dipertimbangkan oleh investor lebih banyak masuk dalam komponen modal intelektual. Namun, pada kenyataannya tipe informasi ini tidak diungkapkan oleh manajer. Hal ini dibuktikan bahwa hanya $1 \%$ dari $93 \%$ sampel perusahaan yang mengungkapkan ramalan pengeluaran riset dan pengembangan dan 2\% yang mengungkapkan perubahan besarnya pengeluaran riset dan pengembangan. Akibatnya kebutuhan informasi ini belum terpenuhi hanya dengan membaca laporan keuangan. Hal ini, menyebabkan adanya "information gap". Fenomena modal intelektual di Indonesia mulai berkembang setelah munculnya PSAK No. 19 (revisi 2000) tentang aset tidak berwujud.

Permasalahannya, perkembangan pengungkapan modal intelektual di Indonesia masih sedikit, hal ini 
disebabkan karena pengungkapan bersifat sukarela yang menimbulkan rendahnya kesadaran perusahaan di Indonesia terhadap pentingnya pengungkapan modal intelektual untuk mempertahankan kompetitif perusahaan (Suhardjanto dan Wardhani, 2010). Walaupun pengungkapan modal intelektual masih bersifat sukarela, tetapi pengungkapan ini diperlukan guna mengurangi asimetri informasi antara pemegang saham dan stakeholder dengan manajer perusahaan. Berdasarkan data tersebut memunculkan pertanyaan apakah perusahaan indonesia telah melaksanakan permintaan informasi terkait dengan modal intelektual. Berhubungan dengan pertanyaan tersebut apakah variabel ukuran perusahaan, profitabilitas, dan leverage berpengaruh terhadap modal intelektual?

Ukuran perusahaan merupakan skala yang menunjukkan besar atau kecilnya perusahaan. Variabel ukuran perusahaan dapat di ukur dengan beberapa proksi seperti total aset, jumlah karyawan, nilai pasar, jumlah penjualan, nilai kapitalisasi pasar saham dan lain-lain. Proksi yang digunakan dalam mengukur ukuran perusahaan adalah total asset karena aset merupakan harta kekayaan atau sumber daya yang dimiliki oleh perusahaan. Semakin besar aset yang dimiliki perusahaan, maka perusahaan dapat melakukan investasi yang baik dan memperluas pangsa pasarnya. Total aset meliputi aset lancar perusahaan dan aset tidak lancar, sehingga dapat lebih mewakili ukuran perusahaan yang sebenarnya (Oktavianti dan Wahidahwati, 2014). Perusahaan besar cenderung berkinerja lebih baik dari pada perusahaan kecil karena sangat diperhatikan oleh publik. Oleh karena itu, perusahaan didorong untuk memberikan informasi yang lengkap dan detail. Perusahaan besar juga akan fokus pada sumber daya manusia seperti karyawan, karena perusahaan besar cenderung memiliki karyawan yang lebih kompeten dibandingkan perusahaan kecil (Utomo, 2015). Perusahaan besar memiliki sumber daya yang cukup untuk mendukung pengungkapan informasi yang lebih banyak dibandingkan perusahaan kecil. Semakin besar perusahaan, semakin banyak aktivitas dan akan mempengaruhi stakeholder (Sinambela, 2019). Maka dari itu dapat disimpulkan semakin besar ukuran perusahaan cenderung memiliki tingkat pengungkapan modal intelektual yang luas.

Profitabilitas merupakan kemampuan mengelola kinerja perusahaan dan evaluasi kinerja manajemen perusahaan yang dapat dilihat dari laba yang dihasilkan (Sinambela, 2019). ROA digunakan untuk mengukur kemampuan perusahaan dalam menggunakan total aset perusahaan untuk menghasilkan laba bersih. Semakin besar nilai ROA perusahaan maka semakin tinggi tingkat laba yang direalisasikan perusahaan, dan semakin baik pula posisi perusahaan dalam penggunaan asetnya (termasuk aset fisik dan modal intelektual) (Sinambela,2019). Profitabilitas yang tinggi dapat menunjukkan kinerja perusahaan yang baik, sehingga dapat diasumsikan sumber daya perusahaan juga baik. Sumber daya perusahaan yang dimaksud yaitu bagaimana perusahaan mengelola aset perusahaan, Semakin besar potensi perusahaan untuk lebih memanfaatkan potensi aset perusahaan (tangible dan intangible asset yaitu modal intelektual) yang dapat meningkatkan nilai tambah perusahaan yang pada akhirnya dapat meningkatkan kinerja keuangan dan menguntungkan stakeholder (Pusparanti, 2018). Pengungkapan modal intelektual adalah informasi berharga bagi investor, yang dapat membantu mereka mengurangi ketidakpastian tentang prospek masa depan perusahaan dan membantu mereka menilai kondisi perusahaan. Selain itu, pengungkapan modal intelektual juga membangun kepercayaan dan rasa aman bagi para stakeholder (Kuncoro, 2018). Hal ini mendorong perusahaan mengungkapkan modal intelektual dan modal intelektual menjadi faktor penentu utama perolehan laba suatu perusahaan dan dianggap sebagai suatu kekuatan dalam mencapai kesuksesan dalam dunia bisnis (Rezki, 2018).

Leverage merupakan pengukur besarnya aktiva yang di biayai dengan pembiayaan utang. Pembiayaan utang disini berasal dari kreditur, bukan dari pemegang saham ataupun investor (Mulyadi dan Siska, 2019). DER (Debt to Equity Ratio) digunakan untuk kemampuan perusahaan dalam memenuhi seluruh kewajibannya yang diwakili oleh seberapa besar ekuitas (modal sendiri) yang digunakan untuk membayar utang. Perusahaan dengan DER yang tinggi diharapkan untuk memenuhi kebutuhan informasi kreditur mengenai struktur modal seperti strategi, kebijakan dan kemampuan untuk melakukan inovasi, karena kreditur membutuhkan informasi yang jelas agar dapat memahami situasi perusahaan dan mempertimbangkan apakah perusahaan dapat melunasi utang para kreditur. Oleh karena itu, perusahaan perlu memberikan informasi yang lebih luas, termasuk pengungkapan modal intelektual (Rizkita, 2017). Menurut Jansen dan Meckling (1976), terdapat hubungan teori agensi dengan leverage. Perusahaan dengan utang yang lebih tinggi dalam struktur modalnya akan menanggung biaya keagenan yang lebih tinggi, dibandingkan dengan perusahaan dengan utang yang lebih rendah. Oleh karena itu, manajemen perusahaan harus lebih transparan kepada pemegang saham untuk menekan biaya keagenan. Semua jenis informasi harus segera dilaporkan kepada pemegang saham, termasuk pengungkapan modal intelektual sebagai pengungkapan sukarela, dengan cara ini pemegang saham dapat memprediksi masa depan perusahaan. Dengan memahami modal intelektual atau aset tidak berwujud yang dimiliki oleh perusahaan, pemegang saham dapat menganalisis dan memahami situasi perusahaan. (Rizkita, 2017). 


\section{METODE}

Jenis penelitian ini adalah penelitian kuantitatif. Penelitian kuantitatif penelitian yang menggunakan model - model matematis atau hipotesis. Penelitian ini bertujuan untuk mengetahui pengaruh ukuran perusahaan, profitabilitas, dan leverage terhadap pengungkapan modal intelektual. Penelitian ini menggunakan 2 jenis variabel yaitu variabel dependan (terikat) dan variabel independen (bebas). Variabel dependen adalah suatu variabel yang nilainya dipengaruhi atau bergantung pada nilai dari variabel lainnya (variabel independen). Variabel dependen pada penelitian ini yaitu pengungkapan modal intelektual (Y). Sedangkan Variabel independen adalah suatu variabel yang menjadi sebab timbulnya atau berubahnya variabel dependen atau bisa diartikan variabel independen adalah variabel yang dapat mempengaruhi variabel dependen. Variabel independen penelitian ini yaitu ukuran perusahaan $\left(\mathrm{X}_{1}\right)$, profitabilitas $\left(\mathrm{X}_{2}\right)$, leverage $\left(\mathrm{X}_{3}\right)$. Populasi yang digunakan dalam penelitian ini adalah perusahaan property dan real estate yang terdaftar di Bursa Efek Indonesia (BEI) pada tahun 2017 - 2019. Teknik pengambilan sampel pada penelitian ini adalah menggunakan purposive sampling yaitu teknik pengambilan sampel yang dilakukan secara tidak acak. Adapun kriteria yang digunakan dalam pemilihan sampel 1) Perusahaan property dan real estate yang mempublikasikan laporan tahunan (annual report) lengkap secara berturut - turut pada periode 2017 - 2019 di Bursa Efek Indonesia, 2) Perusahaan property dan real estate yang mengungkapkan informasi modal intelektual dalam laporan tahuanan di BEI periode 2017 - 2019.

Pengungkapan modal intelektual diukur menggunakan metode content analysis, yaitu menghitung besarnya pengungkapan modal intelektual dengan mengkodekan informasi yang terdapat dalam kerangka modal intelektual yang dipilih. Jika item tersebut diungkapkan dalam annual report perusahaan maka akan mendapat skor sebesar 1. Dan jika item tidak diungkapkan dalam annual report perusahaan, maka nilai item adalah 0 (Sinambela, 2019). Sehingga, indeks Pengungkapan modal intelektual dihitung menggunakan rumus (Brooking dan Annie, 1996) yaitu dengan ICD Index dengan cara membagi jumlah item yang diungkapkan dengan Jumlah dari item indeks pengungkapan modal intelektual (25 item).

Ukuran perusahaan merupakan skala yang menunjukkan besarnya perusahaan. Perusahaan besar cenderung berkinerja lebih baik dari pada perusahaan kecil karena sangat diperhatikan oleh masyarakat. Oleh karena itu, perusahaan didorong untuk memberikan informasi yang lengkap dan detail. Perusahaan besar juga akan fokus pada sumber daya manusia seperti karyawan, karena perusahaan besar cenderung memiliki karyawan yang lebih kompeten dibandingkan perusahaan kecil (Utomo, 2015). Penelitian ini menggunakan proksi total asset dalam mengukur ukuran perusahaan. Total aset dihitung dengan Logaritma Natural (Ln) total asset, karena mencakup aktiva lancar dan aktiva tidak lancar perusahaan, sehingga dapat lebih mewakili ukuran perusahaan yang sebenarnya (Oktavianti dan Wahidahwati, 2014). Pengukuran ukuran perusahaan dapat dirumuskan menurut (Sugiyono, 2014) dengan melogaritma naturalkan total aset. Tingkat profitabilitas diukur menggunakan ROA (return on asset) digunakan untuk mengukur rasio profitabilitas. ROA dapat diukur menggunakan rumus laba bersih setelah dibagi total aset dikalikan seratus persen. Rasio leverage merupakan alat yang digunakan untuk mengukur besarnya aset yang dibiayai oleh hutang. Jenis rasio leverage penelitian ini menggunakan rasio DER (Debt to Equity Ratio). Menurut Kasmir (2014), DER adalah kemampuan perusahaan dalam memenuhi seluruh utangnya yang diwakili oleh seberapa besar modal sendiri yang digunakan untuk melunasi utang. Semakin tinggi DER maka semakin rendah kemampuan perusahaan untuk membayar seluruh kewajibannya. Oleh karena itu, perusahaan dengan DER yang lebih tinggi diharapkan dapat memenuhi kebutuhan informasi kreditur jangka panjang dengan menyediakan informasi yang lebih luas (terutama pengungkapan modal intelektual) (Amalia, 2017). Leverage dihitung menggunakan rumus DER menurut (Kasmir, 2012:155) yaitu dengan membagi total kewajiban dengan total ekuitas.

\section{HASIL DAN PEMBAHASAN}

Penelitian ini menggunakan analisis regresi linear berganda untuk menganalisis data dan menjelaskan hubungan antara variabel independen terdahap dependen. Berikut ini Tabel 1 yang menunjukkan output regersi dari penelitian ini.

Tabel 1. Ringkasan Output Regresi

\begin{tabular}{|c|c|c|c|c|c|c|}
\hline No & Variabel & & Koefisien & t-hitung & t-tabel & Prob. \\
\hline 1 & Konstanta & & $-0,926$ & $-3,601$ & 1,982 & 0,000 \\
\hline 2 & Ukuran Perusahaan & & 0,054 & 5,981 & 1,982 & 0,000 \\
\hline 3 & ROA & & 0,173 & 0,603 & 1,982 & 0,548 \\
\hline 4 & DER & & $-0,002$ & $-0,091$ & 1,982 & 0,927 \\
\hline & $\begin{array}{l}\text { Konstanta } \\
\text { Adjusted R Square } \\
\text { Fhitung } \\
\text { F tabel }\end{array}$ & $\begin{array}{l}=-0,926 \\
=0,234 \\
=13,843 \\
=2,690\end{array}$ & & & & \\
\hline
\end{tabular}

Sumber: Output Regresi, 2021

Hasil penelitian menunjukkan bahwa uji bersamasama atau Uji $\mathrm{F}$ menunjukkan bahwa nilai $\mathrm{F}$ hitung $(13,843)$ lebih besar daripada $F$ tabel $(2,690)$. Dengan demikian, dapat disimpulkan bahwa, ukuran perusahaan, profitabilitas, dan leverage secara bersama-sama berpengaruh terhadap pengungkapan modal intelektual pada perusahaan properti dan real estat yang terdaftar di Bursa Efek Indonesia pada Periode 2017 - 2019. 


\section{Pengaruh ukuran perusahaan terhadap pengungkapan modal intelektual}

Berdasarkan hasil analisis mengenai pengaruh ukuran perusahaan terhadap pengungkapan modal intelektual menunjukan ukuran perusahaan memiliki nilai koefisien 0,054 dan nilai t-hitung 5,981 lebih besar dari nilai t-tabel 1,982 Dengan demikian, dapat disimpulkan bahwa variabel ukuran perusahaan berpengaruh signifikan terhadap pengungkapan modal intelektual. Perusahaan properti dan real estate periode 2017 - 2019 yang memiliki total aset tertinggi diperoleh oleh PT PP Properti Tbk sebesar Rp. 164.757.204.862.845 dengan tingkat pengungkapan modal intelektual 92\% dimana mengungkapkan 23 item dari 25 item yang seharusnya diungkapkan dalam annual report. Berdasarkan hal tersebut, terbukti bahwa semakin besar ukuran perusahaan, cenderung semakin tinggi tingkat pengungkapan modal intelektual karena semakin besar ukuran perusahaan, semakin tinggi tuntutan terhadap keterbukaan informasi dibandingkan perusahaan yang lebih kecil. Selain itu perusahaan yang besar sering mengalami agency conflict karena memiliki stakeholder yang banyak dan tersebar luas. Agency conflict dapat diminimalisir dengan dengan adanya pelaporan informasi financial maupun non - financial yang ditunjukkan kepada stakeholders sebagai pertanggungjawaban manajemen. Maka dari itu, perusahaan besar cenderung melakukan pengungkapan modal intelektual dengan tujuan untuk mengurangi biaya keagenan. Hasil penelitian ini sejalan dengan penelitian (Rezki, 2018), (Sari dan Yulida, 2018), (Fajarrisqim, Mohamad dan Afifudin, 2018), (Sinambela, 2019), menyatakan bahwa ukuran perusahaan berpengaruh signifikan terhadap pengungkapan modal intelektual.

\section{Pengaruh profitabilitas terhadap pengungkapan modal intelektual}

Selanjutnya profitabilitas tidak berpengaruh signifikan terhadap pengungkapan modal intelektual ditunjukan dengan nilai koefisien sebesar 0,173 dan nilai t-hitung 0,603 lebih kecil dari nilai t-tabel 1,982. Hal ini disebabkan beberapa perusahaan properti dan real estat mengalami kerugian. Oleh sebab itu, penelitian ini membuktikan bahwa besar kecilnya profitabilitas tidak dapat menjadi tolak ukur pengungkapan modal intelektual pada laporan tahunan perusahaan properti dan real estat tahun 2017 sampai 2019. Alasan profitabilitas tidak berpengaruh terhadap pengungkapan modal intelektual pada perusahaan property dan real estate tahun 2017 - 2019, karena perusahaan hanya memaksimalkan potensi aset yang berasal dari aset berwujud saja, tanpa memperhatikan kemampuan aset tak berwujud yang dimiliki perusahaan. Hal tersebut disebabkan karena biaya yang mahal untuk memperoleh modal intelektual yang unggul, sebagai contoh untuk memperoleh sumber daya manusia yang kompeten harus mengeluarkan biaya gaji yang tinggi atau membutuhkan biaya yang besar untuk pelatihan dan pengembangan kompetensi sumber daya manusia. Penyebab lain yang dihadapi perusahaan adalah dalam segi pemasaran. Iklan merupakan sarana penunjang untuk persaingan produk. Iklan yang dibuat sangat didukung oleh kreatifitas sumber daya manusia sehingga dapat menampilkan keunikan produk yang dapat meningkatkan daya beli konsumen, hal ini membutuhkan biaya yang mahal (Iswati, 2007). Hasil penelitian ini sejalan dengan penelitian Sari dan Yulida, (2018), Amalia,(2017), Nugroho (2017), menyatakan bahwa profitabilitas tidak berpengaruh dengan pengungkapan modal intelektual.

\section{Pengaruh leverage terhadap pengungkapan modal intelektual}

Berdasarkan hasil analisis dijelaskan bahwa variabel leverage memiliki nilai koefisien sebesar $-0,002$ dan nilai t-hitung -0,091 lebih kecil dari t-tabel 1,982 dengan demikian, dapat disimpulkan variabel leverage tidak mempunyai pengaruh signifikan terhadap pengungkapan modal intelektual. Alasan tingginya leverage tidak mempengaruhi pengungkapan modal intelektual karena sebagian perusahaan property dan real estate yang terdaftar di Bursa Efek Indonesia merupakan perusahaan keluarga. Hal ini dibuktikan dari 37 sampel perusahaan property dan real estat yang dipakai dalam penelitian terdapat 22 perusahaan properti dan real estat termasuk perusahaan keluarga. Perusahaan dengan struktur kepemilikan keluarga dianggap memiliki reputasi baik karena adanya keterlibatan keluarga, baik dalam manajemen atau pun sebagai pemegang saham. Konsistensi keluarga untuk terus terlibat dengan perusahaan, memberikan keyakinan kepada kreditur bahwa akan ada hubungan jangka panjang yang dapat dibina dengan perusahaan keluarga yang dapat menjamin perjanjian utang berjalan sebagaimana mestinya. Oleh karena itu, tingginya leverage tidak mempengaruhi pengungkapan modal intelektual, karena pihak kreditur percaya dan tidak ada keraguan atas jaminan dana yang dipinjamkan kepada perusahaan. Perusahaan juga dianggap memiliki reputasi baik dihadapan investor dan stakeholder sehingga tidak ada keraguan terhadap kondisi perusahaan mengenai keberlanjutan perusahaan. Hasil penelitian ini sejalan dengan penelitian Mulyadi dan siska, (2019), Sari dan Yulida, (2018), Nishak, (2017), menyatakan bahwa tidak ada pengaruh antara variabel leverage dengan pengungkapan modal intelektual.

\section{SIMPULAN}

Berdasarkan hasil penelitian bahwa variabel profitabilitas dan leverage tidak mempunyai pengaruh terhadap variabel pengungkapan modal intelektual serta variabel ukuran perusahaan mempunyai pengaruh positif terhadap variabel pengungkapan modal intelektual. Implikasi dari penelitian ini adalah mendukung penelitian (Rezki, 2018), (Sari dan Yulida, 2018), 
(Fajarrisqim,Mohamad dan Afifudin, 2018), (Sinambela, 2019), menyatakan bahwa ukuran perusahaan berpengaruh signifikan terhadap pengungkapan modal intelektual, sejalan dengan penelitian Sari dan Yulida, (2018), Amalia (2017), Heviani (2017), Nugroho (2017), menyatakan bahwa profitabilitas tidak berpengaruh dengan pengungkapan modal intelektual dan penelitian Mulyadi dan siska, (2019), Sari dan Yulida, (2018), Nishak, (2017), menyatakan bahwa tidak ada pengaruh antara variabel leverage dengan pengungkapan modal intelektual

\section{DAFTAR PUSTAKA}

Amalia, Nur Indah. (2017). Pengaruh Profitabilitas, Ukuran Perusahaan, Dan Leverage Terhadap Pengungkapan modal intelektual. Jurnal Akuntansi. STIE Perbanas Surabaya.

Author, Hafza Neill., \& Agus, Purwanto. (2017). FaktorFaktor Yang Memengaruhi Pengungkapan Modal Intelektual. Diponegoro Journal Of Accounting, 113.

Brooking, \& Annie. (1996). IC: Core Assets for Third Millenium Enterprise.Thomson Business Press. London-England. Diadopsi oleh Partanen, Timo 1998:66 (39).

Fajarrisqim, Sigit., Mohammad, Amin., \& Afifudin (2018). Pengaruh Ukuran perusahaan, Tipe Industri, Leverage Pada Pengungkapan Modal Intelektual(Studi Empiris Perusahaan Manufaktur Yang Listing Di Bei Tahun 2014-2016).

Iswati, Sri. (2007). Memprediksi Kinerja Keuangan Dengan Modal Intelektual pada Perusahaan Perbankan Terbuka di Bursa Efek Jakarta. Ekuitas. Vol. 10 (02).

Jansen, Michael C. \& Meckling, William H. 1976. Theory of the Firm: Managerial Behaviour, Agency Cost, and Ownership Structure. Journal of Financial Economics,3.

Kasmir. (2012). Analisis Laporan Keuangan. Jakarta: PT. Raja Grafindo Persada.

Kuncoro, Wahyu. (2018). Faktor-Faktor Yang Mempengaruhi Pengungkapan Modal Intelektual (Studi Pada Perusahaan Sektor Properti, Real Estate, Dan Konstruksi Bangunan Tahun 2013-2015 Yang Terdaftar Di Bei). Jurnal Akuntansi. Universitas Islam Indonesia

Mulyadi, \& Ariyanti, Siska. (2019). Pengaruh Ukuran Perusahaan, Firm age, Leverage, Return On Assets Dan Komisaris Independen Terhadap Pengungkapan modal intelektual (Pada Perusahaan Manufaktur Yang Terdaftar Di Bursa Efek Indonesia Periode 2013-2016). Competitive 2 (2). 95 - 106.

Nishak, Choirun. (2017). Pengaruh Profitabilitas, Leverage, Ownership Etention Dan Ukuran Perusahaan Terhadap Pengungkapan modal intelektual Pada Perusahaan Yang Melakukan Initial Public Offering. Jurnal Akuntansi. STIE Perbanas Surabaya.

Nugroho, Agung. (2017). Pengaruh Leverage, Profitabilitas, Komisaris Independen Dan
Konsentrasi Kepemilikan Terhadap Pengungkapan modal intelektual (Studi Empiris Pada Perusahaan Manufaktur Yang Terdaftar Di Bursa Efek Indonesia Periode 2014-2015). Jurnal Akuntansi. Universitas Muhammadiyah Surakarta.

Oktavianti, H., \& Wahidahwati, 2014, Faktor-Faktor yang Mempengaruhi Pengungkapan Modal intelektual, Jurnal Ilmu dan Riset Akuntansi, Vol. 3, No. 5.

Pusparanti, Pramesti. (2018). Faktor-Faktor Yang Mempengaruhi Pengungkapan modal intelektual(Studi Kasus Pada Perusahaan Property And Real Estate Yang Terdapat Pada Bei 20132016). Jurnal Akuntansi. Universitas Islam Indonesia.

Rezki, Sri Budhi. (2018). Determinan Faktor Pengungkapan Modal Intelektual Dan Tingkat Pengungkapan Per Industrinya Pada Seluruh Perusahaan Yang Terdaftar Di Bursa Efek Indonesia. Jurnal Ilmiah Akuntansi, 95-108 .

Rizkita. (2017). Faktor-Faktor Yang Mempengaruhi Pengungkapan modal intelektual (ICD) Pada Perusahaan Property Dan Real Estate Yang Terdaftar Di Bursa Efek Indonesia (BEI). Jurnal Akuntansi. Universitas Negeri Semarang.

Sari, Eka Nurmala., \& Yulida, Arisanti. (2018). Pengaruh Karakteristik Perusahaan Terhadap Tingkat Pengungkapan modal intelektual Di Dalam Laporan Tahunan (Studi Pada Perusahaan Food And Beverages Yang Terdaftar Di Bursa Efek Indonesia Tahun 2010-2014). Jurnal Akuntansi Dan Keuangan Methodist, 108-122 .

Sinambela, Ria Melina Debora. (2019). Pengaruh Ukuran Perusahaan, Firm age, Profitabilitas, Dan Leverage Terhadap Pengungkapan modal intelektual (ICD) Pada Perusahaan Keuangan Yang Terdaftar Di Bei Periode 2013-2017 . Jurnal Akuntansi. Universitas Sumatera Utara.

Sugiyono. (2012). Metode Penelitian Kuantitatif Kualitatif dan $R \& B$. Bandung: Alfabeta.

Suhardjanto, Djoko., \& Wardhani, Mari. (2010). "Praktik Pengungkapan modal intelektual Perusahaan yang Terdaftar Di Bursa Efek Indonesia”. JAAI. 14, (1),71-85.

Utomo, Annisa Iddiani. (2015). Faktor-faktor Yang Mempengaruhi Pengungkapan Modal Intelektual dan Dampaknya Terhadap Nilai Perusahaan. Skripsi. Semarang: Universitas Diponegoro.

Yenita, Riri., \& Efrizal, Syofyan. (2018). Pengaruh Karakteristik Perusahaan, Kinerja Perusahaan, Dan Diversitas Dewan Komisaris Terhadap Pengungkapan Modal Intelektual (Studi Empiris Pada Perusahaan Manufaktur Yang Terdaftar Di Bei Tahun 2014-2016). Jurnal Wahana Riset Akuntansi. Vol. 6, No. 1. 